СМИ. Мир науки, культуры, образования, (6 (85)), 616-619. DOI: 10.24412/1991-5500-2020-685-616-619

2. Aslam, F., Awan, T.M., Syed, J.H. et al. Sentiments and emotions evoked by news headlines of coronavirus disease (COVID-19) outbreak. Humanit Soc Sci Commun 7, 23 (2020). https://doi.org/10.1057/s41599-0200523-3

3. Coronavirus. (n.d.) Retrieved from: https://bit.ly/3v3bTIe (accessed 18 April 2021).

4. Coronavirus. (n.d.) Retrieved from: https://bit.ly/3dtZqI0 (accessed 18 April 2021).

5. Editors of Encyclopaedia Epidemic. Encyclopedia Britannica. (2020) Retrieved from: https://www.britannica.com/science/epidemic (accessed 18 April 2021).

6. Martin, P., Martin-Granel, E. (2006) 2,500-Year Evolution of the Term Epidemic. Emerging infectious diseases, vol. 6, no. 12, pp. 976-80. Retrieved from: 10.3201/eid1206.051263 (accessed 10 March 2021).

7. Pandemic. (n.d.) Retrieved from: https://bit.ly/3alEgK7 (accessed 18 April 2021).

8. Roget's 21st Century Thesaurus, 3rd edition. (2005) New York: A Delta Book.

DOI https://doi.org/10.30525/978-9934-26-073-5-1-50

\title{
THE DYNAMIC PARAMETER OF INTONATION OF RURAL STATIC LANDSCAPE DESCRIPTIONS IN ENGLISH PROSE
}

\author{
Humeniuk I. L. \\ Doctor of Philosophy, \\ Senior Lecturer at the English Language Chair \\ Sumy State Pedagogical University named after A. S. Makarenko \\ Sumy, Ukraine
}

The problem of defining, classifying the description as one of compositeand-speech forms of a fiction text, distinguishing its lexical and grammar peculiarities and ascertaining its role and place in the text is not new in the sphere of philological research. The description, and the landscape description in particular, attracted attention of many scholars who viewed it in many aspects, in linguistic and artistic ones as well. But studying landscape descriptions didn't lose its actuality in the facet of its intonation organisation, 
since during its oral actualisation a listener can fully percept a multicolourful landscape, which is reproduced by the combination of intonation means among which its dynamic component takes an important place. In view of this, we think it is important to consider originality of loudness modifications functioning in intonation organisation of rural static landscape descriptions as one of the kinds of description texts. The objective of the paper is to ascertain the functioning of the dynamic parameter in English prosaic rural static landscape descriptions' intonation by means of performing its auditory analysis. The intonation characteristic under study is included into the invariant intonation pattern of these landscape descriptions. It enables their differentiation in comparison with other landscape descriptions.

At the same time direct studying of intonation means of landscape descriptions' actualisation needs, in our view, grounding and systematization of the present diversity of linguistic features, which are distinctly correlated with the experimental phonetic study's tasks. The classification of linguistic features of landscape descriptions in English prose [1, s. 165-169] is developed taking into account different criteria, among which locality type is the main one. The developed in such a way classification can serve as a reliable ground for working out the methodology of experimental phonetic study of the dynamic peculiarities of rural static landscape descriptions' intonation organisation.

Methodological basis of our research is a functional and communicative approach to studying specificity of landscape descriptions' intonation, and static descriptions in particular [3]. We also used general theoretical and phonological views of scholars on mechanisms and laws of segmental and suprasegmental units' functioning in oral prosaic texts [4, s. 139-146; 5, s. 200-203; 7, s. 169-177].

The auditory analysis was aimed to studying loudness modifications in intonation of static descriptions of the rural area. To fulfil the practical part of the study we developed a complex programme and methodology of the research according to which the experimental defining of common and differential features of invariant and variant intonation patterns was made to state the intonation means' interaction regularities in English rural static landscape descriptions' realisation [2, c. 161-165]. The experimental study programme included the following steps: the choice of language material and its presenters, landscape descriptions' auditory analysis by phoneticians, summary of the experimental results and their linguistic interpretation. The suggested methodology guaranteed a succession of experimental material corps formation and sequence of auditory analysis. Observance of all the experimental phonetic study programme and methodology stages made it 
possible to fulfil rural static descriptions' auditory analysis and make an adequate interpretation of the obtained results.

Generalized data of loudness variants' frequency in rural static descriptions prove that moderate loudness $(81,81 \%)$ is characteristic for them. Its fluctuations from a lowed to a raised variant are stipulated by rural landscape descriptions' kind and the level of emotional-and-pragmatic potential. The highest recurrence of a moderate variant and insignificant rate of raised loudness $(12,12 \%)$ are inherent for static descriptions. The high frequency of moderate loudness is explained by different reasons: in rural static descriptions it marks establishment of the known information, facilitates conveying tranquility or silence of an evening/night landscape. Meanwhile the cases of lowing down loudness $(6,06 \%)$ in some communicatively important words. Their degree of contrast in respect to other words attracts a listener's attention.

Such a tendency of loudness modifications in rural static landscape descriptions can be observed in the example below:

"The 'storm had 'evidently 'broken ·during the n/night, | though 'huge 'sea was $\uparrow_{\text {still }}{ }_{n}$ /running $\xi$ and a 'stiff 'wind ${ }_{n}$, blowing. II 'Sail had been w/ made $\xi$ in the 'early w/ watches, $\xi$ so that the 'Ghost was 'racing $a_{w}$ long $\xi$ under, everything $\xi$ ex'cept the 'two ${ }_{w}{ }_{1}$ topsails $\xi$ and the 'flying ,jib \|" [6, c. 202].

This sea description has a high level of emotional-and-pragmatic potential due to accelerated tempo and pitch range modifications from a narrowed variant (e.g. The 'storm had 'evidently'broken •during the ${ }_{n} / n i g h t$, | though 'huge 'sea was $\uparrow_{\text {still }}$ / running $\xi$ and a 'stiff 'wind ${ }_{n}$, blowing .\|) to a widened variant (e.g. 'Sail had been ${ }_{w}$ made $\xi$ in the 'early ${ }_{w} v$ watches, $\}$ so that the 'Ghost was 'racing $a_{w}$ long $\xi$ under, everything $\xi$ ex'cept the 'two ${ }_{w}{ }_{1}$ topsails $\xi$ and the 'flying,$j i b . \|$, etc.). Moreover mid and narrowed pitch intervals between tone groups, domineering of rising terminal tones, approximately equal prominence and clear pronouncing of each notion word, distinct rhythm made it possible to define a mid level of its emotional-andpragmatic potential. The static nature of the analyzed description is stated first of all due to moderate loudness in combination with temporal modifications from an accelerated variant (e.g. 'Sail had been, made $\xi$ in the 'early $\vee$ watches, $\xi$, etc.) to a moderate variant (e.g. ...so that the 'Ghost was 'racing a, long $\xi$ under, everything $\xi$ ex'cept the 'two \topsails $\xi$ and the 'flying ,jib.\|) in some parts, accentuating the adverb still with the special rise for emphasizing that the storm has not abated down yet. 
Thus, rural static landscape descriptions are characterized by loudness modifications from a moderate variant to a lowed one or from a moderate variant to a raised one. Together with the organisation chiefly by low falling and rising tones with a low rate of their movement change it gives descriptions mainly a mid and low level of emotional-and-pragmatic potential.

Consequently, the results of the carried out auditory analysis enable distinguishing loudness variations in the invariant intonation pattern of rural static descriptions' actualisation. Thus, rural static descriptions are pronounced with raised, moderate and lowed loudness.

The obtained auditory analysis data prove that rural static landscape descriptions have specific intonation which enables their adequate identification by a listener. We consider, that the experimental results presented in the paper can become a basis for further studying of intonation characteristics of landscape descriptions in other languages.

\section{References:}

1. Гуменюк І.Л. Систематизація ознак описів природи сучасної англомовної прози. Наукові записки. Серія: Філологічні науки (мовознавство). 2009. Вип. 81 (2). С. 165-169.

2. Гуменюк І.Л. Експериментально-фонетичне дослідження англомовних прозових описів природи. Вісник Черкаського університету, Серія: Філологічні науки. 2011. Вип. 213. С. 161-165.

3. Калита А.А. Фонетичні засоби актуалізації смислу англійських емоційних висловлювань. Київ, 2001. 351 с.

4. Лисичкіна I.О. Просодична домінанта англомовного дискурсу реклами. Вісник Київського начіонального лінгвістичного університету, Серія: Філологія. 2004. Т. 7. № 2. С. 139-146.

5. Рубчак О.Б. Аудитивний аналіз просодичної організації англомовних підготовлених радіо- і телеінтерв'ю. Наукові записки Національного університету "Острозька академія". Серія: Філологічна. 2015. Вип. 53. С. 200-203.

6. London J. Tales of the North: The complete novels of White Fang, The Sea-Wolf, The Call of the Wild, The Cruise of the Dazzler plus fifteen short stories. Secaucus, 1979. $488 \mathrm{p}$.

7. Taranenko L., Schafer S. Prosodic Expression of Emotional-AndPragmatic Potential of a Spoken English Proverb. Advanced Education. 2018. Vol. 9. P. 169-177. 